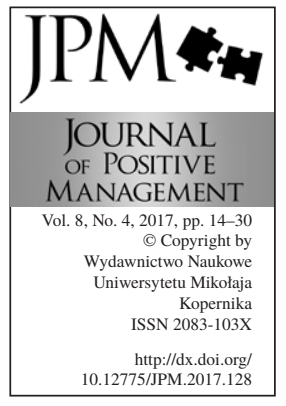

\title{
THE SIGNIFICANCE OF PEOPLE-ORIENTED MANAGEMENT AND PARTICIPATION FOR MENTORING IN ORGANIZATIONS
}

\author{
${ }^{a}$ Małgorzata Baran, ${ }^{b}$ Barbara Sypniewska \\ ${ }^{\mathrm{a}, \mathrm{b}}$ Collegium Civitas, Warsaw, Poland \\ The University of Finance and Management, Warsaw, Poland \\ ae-mail: malgorzata.baran@civitas.edu.pl \\ bemail: agata.sypni@op.pl
}

\begin{abstract}
Purpose: The objective of the study was to identify the correlations among the following variables: supporting mentoring processes in a company by the superior; fulfilling the role of a mentor by the superior; and fulfilling the role of a mentor by employees versus passive and active participation in company management, people-oriented and non-people-oriented management; the possibility of frequently turning to the superior with personal problems or for help; and ease of contact between employees and the superior.

Methodology: The article presents the findings of own study carried out in 2017 on a sample of 975 respondents. The study employed the subject literature critical review method and a questionnaire survey.

Findings: The results show the importance of subject management and employee participation in organizations, and its meaning for the proper implementation of mentoring.

Research limitation: The work may be affected by the inherent weaknesses associated with survey research which examines rather opinions and views than "hard data".

Originality: Recent mentoring research has pointed to various aspects of its success, but the mentoring process has not been studied yet in terms of the impact of the following variables: supporting mentoring processes in a company by the superior; fulfilling the role of a mentor by the superior; and fulfilling the role of a mentor by employees versus passive and active participation in company management, people-oriented and non-people-oriented management; the possibility of frequently turning to the superior with personal problems or for help; and ease of contact between employees and the superior. In addition, previous research did not take into account the use of such statistic models that were presented in this article.
\end{abstract}

Keywords: mentoring, people-oriented management, non-people-oriented management, passive participation, active participation

Paper type: Research paper 


\section{Introduction}

Referring to the changes in human resources management in the $21^{\text {st }}$ century, Drucker concluded that there are many different ways to manage people but none is perfect (Grajewski, 2010). A claim formulated in such a way motivates to search for the best ways to succeed on a competitive market in these uncertain times. Changes in the approach to the human capital, its development and human resources management have been taking place since the $19^{\text {th }}$ century. The economic and rational human being supervised by a strict Tayloristic manager was replaced by a social and spiritualized man. Such an approach meant an individualistic attitude to an employee. Management methods were adjusted and in time adopted the name: people-oriented management. Attention has been directed towards employees' cooperation and co-deciding in various areas of an organization's operation, i.e. towards employee participation. Contemporary organizations place great emphasis on the development of the human capital. One of the forms of improvement is mentoring oriented at the development of employees in a different way than the traditional one-time training. Mentoring is an open and partner relation between the master and the student, which is oriented both at personal and professional development. The aim of the paper is to present the findings of own study carried out in 2017 on a sample of 975 respondents. Its objective was to identify the correlations among the following variables: supporting mentoring processes in a company by the superior; fulfilling the role of the mentor by the superior; and fulfilling the role of the mentor by employees versus passive and active participation in company management; people-oriented and non-people-oriented management; the possibility of frequently turning to the superior with personal problems or for help; and ease of contact between employees and the superior.

\section{People-oriented and non-people oriented management and direct participation}

At the turn of the $20^{\text {th }}$ and $21^{\text {st }}$ century, the dominant management model was non-people oriented. This model referred to as the traditional one (i.e. scientific management, administrative management) was based on the classic management school led by Taylor, who coined the term 'homo economicus'. An individual is supposed to work using the maximum of their physical and mental capabilities in order to obtain the highest possible remuneration (Cascio, 1992). Describing a company operating in this model, Zając claimed that it is closed, formalized, and the role of the employee boils down to passively following the superiors' orders. Whereas the superior acts as an executor and controller, while motivation is only achieved through economic incentives and coercive means (Zając, 2014). With time the role of the human capital in an organization has gained recognition and the workers started to be treated as a value in itself. Such an approach was
THE SIGNIFICANCE OF PEOPLE-ORIENTED MANAGEMENT

Małgorzata Baran, Barbara Sypniewska 
THE SIGNIFICANCE OF PEOPLE-ORIENTED

MANAGEMENT

Małgorzata Baran,

Barbara Sypniewska ushered in by a model of interpersonal relations (Król, 2006), which refers to the psychosocial current in management based on people-oriented treatment of workers (among others: Mayo, Likert, Argiris, Herzberg). It was argued that in order to achieve greater efficiency people must work 'together' and not 'over' or 'under' one another; co-workers should treat each other as partners and cooperation should be ensured on all levels of the organization; hence emphasis was placed on cooperation and good interpersonal relations (Chodorek, 2016; Martyniak, 2002; Robbins and DeCenza, 2002; Butler et el., 1991; Kurnal, 1969). A company operating in this model adopts an assumption that good atmosphere, friendliness, absence of conflicts, harmonious cooperation, and participation of workers in management allows to gain competitive advantage. Pocztowski believes that the new approach to a human being in an organization consists in offering the employee opportunities that are priority for the strategic operations of a business and not treating them as a source of costs (Pocztowski, 2008). The essence of contemporary human resources management is based on the significance attached to employees, people-oriented approach (Gableta, 2004), and treating the human capital as an important and necessary factor for achieving good results and gaining competitive advantage by companies (Barney and Wright, 1998; Delaney and Huselid, 1996; Hsu et al., 2007; Sandberg, 2000; Wang and Chen, 2013). In return for people-oriented treatment and creating appropriate working conditions, the employer expects the employee to demonstrate a positive attitude, integrity, commitment, readiness to learn and share knowledge and accept coresponsibility for the success of the company (Rybak, 2004); whereas an engaged worker can help the organization at times of turbulent changes in its environment (Marchington and Kynighou, 2012).

Blikle indicates that the leader in people-oriented management controls the behaviours of the team members by referring to their needs for virtue; he or she is not an arbitrary holder of tangible benefits and endeavours not to allow the 'rat race' to commence by stressing that there are no better and worse employees and that each worker is endowed with a specific talent. Whereas the leader in non-people-oriented management refers primarily to the benefits that he or she is an arbitrary holder of and the leader is the one to decide who deserves them. The members of the team are compared to one another by dividing them into better and worse ones, thus creating an atmosphere of rivalry, competition and the so-called 'rat race' (Blikle, 2017). The results of some studies confirm that by treating an employee as a partner, adopting the people-oriented approach to an employee, and thus addressing their need for dignity and respect as well as giving them the sense of agency and purposefulness of their actions, it is possible to increase the degree of an employee's identification with the company (Sypniewska, 2016) and lead the business to victory over the problems arising from changes in its environment. 
Employee participation in the management process triggers the sense of responsibility in workers for the company's fate and results. It is important that the worker himself or herself feels what is advantageous and profitable and how he or she could contribute to the company's success. Therefore, cooperation, comanagement, and co-deciding (Mendel, 2001) play a very important role for the operation of an organization. In other words, participation of workers in every aspect of the functioning of a business is welcome and referred to as employee participation in the relevant literature. The aim of participation is to increase employees' involvement and enable them to satisfy their higher needs such as self-realization, recognition, and affiliation by giving them the possibility to make decisions and participate in the management of the organization. Participation means influencing employer's operations to a varying degree and extent; it facilitates openness to communication, discussions about problems, influencing decision-making, and consultations (Sekuła, 2015). It may thus be concluded that participation is becoming more and more important for contemporary companies (Chyłek, 2011). One of the forms of participation is direct participation that refers to employees' individual involvement in certain processes which were previously single-handedly handled by the management (Ignyś, 2014; Knudsen, 1995). In practice, this is relevant for decisions made at lower management levels and the decisions on how to perform tasks. According to Sisson and Geary, direct participation is an "initiative that the management uses to allows individual workers or teams to hold consultations and delegate to employees the authority and responsibility for decisions regarding the organization and working conditions as well as the choice of how to perform tasks on a given position" (Lochnicka, 2013). In view of the need to create an organizational climate fostering development and growth of employee engagement, organizations should place particular emphasis on direct forms of participation (Mikuła, 2000). The levels of participation singled out by Tegtmeier - passive and active participation - were adopted for the purposes of this study. Passive participation/cooperation is concerned with the right to information, the right to voice complaints, the right to speak up (give opinions), and the right to obtain advice. While active participation/co-deciding pertains to the right to object, express consent, and the right to resolve matters jointly. According to Tegtmeier, cooperation means that workers may affect the operation of the management, but only if the management finds their contribution significant. Co-deciding, on the other hand, encompasses forms offering employees more real possibilities of exerting influence over organization management (Ignyś, 2014; Piotrowski and Świątkowski, 2000; Ziemniewicz, 1991; Mikuła, 2000).

\section{Mentoring}

Today organizations are not only looking for different methods of management but also developing the human capital. Partnership and dialogue in an organization

THE SIGNIFICANCE OF PEOPLE-ORIENTED MANAGEMENT

Małgorzata Baran, Barbara Sypniewska 
THE SIGNIFICANCE OF PEOPLE-ORIENTED

MANAGEMENT

Małgorzata Baran,

Barbara Sypniewska on every level of the decision-making process, openness to the ideas of others, mutual respect, people-oriented approach to employees, and employee participation create a favourable atmosphere for achieving targets. One of the forms of human capital development is mentoring, which has various definitions in the relevant literature. Mentoring is a long process based on a mutual relation between two people, the master and the student, where one person (i.e. the mentor) is responsible for supervising the career and development of the second person (i.e. the student) (Clutterbuck, 2002). This relation is based on inspiration, stimulation, and leadership, which allows the student to learn things about himself or herself, develops his or her self-awareness, and achieve selfrealization in professional life (Karwala, 2009). The partnership and dialogue that were mentioned above contribute to the development of the mentoring process in an organization. According to Oleksyn, "mentoring consists in constant contact of an inexperienced employee with the mentor who introduces him or her into the professional environment and duties" (2006). An employee takes part in the mentoring process with the mentor, who is his or her master and advisor at work. There is a widespread claim in the literature that it is the superior who fulfils the role of the mentor for an employee in his or her working environment (Parsloe and Wray, 2002; Suchar, 2003). A mentor may be a person from another part of the company; someone whose age, knowledge, and talents predestine them to this role and allow them to work with a person undergoing mentoring by way of setting career goals together, developing action plans or discussing the results of actions that have been taken (Parsloe and Wray, 2002; Suchar, 2003). However, not every person that is willing to do so may become a mentor since the mentor's role in the process of mentoring is difficult and complex - the mentor is a teacher and simultaneously an authority figure, the leader and advisor, expert and assessor (Parsloe, 2000; Baran, 2016b; Garvey and Alred, 2001). The person whose posture, knowledge, and competence make them trustworthy, a model to emulate, someone who is capable of inspiring and supporting - has the biggest chances of bringing about changes in another person (Baran, 2016a). According to Clutterbuck (2002), "a mentor is a more experienced individual willing to share knowledge with someone less experienced in a relationship of mutual trust". "Mentors are people, who through their action and work, help others to achieve their potential" (Shea, 1992; Parsloe and Wray, 2002). In the mentoring process, the superiors' support is extremely important (Allen, 2007). Without approval and support of senior management, even if the process taking place in the organization is designed in the best way, it will not be successful.

\section{Research methodology}

In the first quarter of 2017, a quantitative questionnaire survey was conducted on a group of 1027 respondents with the use of a survey questionnaire. The 
presented study is part of a complex research project carried out by the authors of this paper. The respondents were selected by way of purposive sampling. The selection criterion was employment in a company operating in Poland, regardless of company size.

The objective of the study was to identify the correlations among the following variables: supporting mentoring processes in a company by the superior; fulfilling the role of the mentor by the superior; and fulfilling the role of the mentor by employees versus passive and active participation in company management; people-oriented and non-people-oriented management; the possibility of frequently turning to the superior with personal problems or for help; and ease of contact between employees and the superior. The following questions were formulated during the research process:

1) What is the character of correlations among the above-mentioned variables?

2) What are the key predictors of supporting mentoring in a company by the superior?

3) What are the key predictors of assuming the role of the mentor by the superior?

4) What are the key predictors of carrying out mentoring in a company by the employees?

People-oriented and non-people-oriented management were analysed using statements in the questionnaire that reflected the way employees are treated in a company. As far as people-oriented management is concerned, the statements pertained to: treating workers as a value in itself and as partners; preference for cooperation in performing tasks as a team; placing trust in employees and respecting them; treating workers as creative and entrepreneurial individuals; the superiors' ethical conduct; stirring the willingness to act and supporting employees; appreciation of employees' work by the superiors; delegating tasks eagerly; and the superiors' decision-making capabilities and accountability. Whereas non-people-oriented management referred to the following statements: treating employees in line with the rule that a man is worth as much as he or she earns for the business; holding a view that employees are generally lazy and dishonest so they must be controlled; treating employees as 'cogs in the machine'; ignoring workers; disregarding even small successes; dividing workers into better and worse ones by creating the atmosphere of the rat race; and superiors avoiding talking to employees.

In the course of the questionnaire survey, the respondents were also asked about passive and active participation. Statements about passive participation were concerned with employees' possibilities of making complaints; receiving advice in problematic situations, expressing their opinion about the circumstances surrounding the company and the department or decisions to be reached; and
THE SIGNIFICANCE OF PEOPLE-ORIENTED MANAGEMENT

Małgorzata Baran, Barbara Sypniewska 
THE SIGNIFICANCE OF PEOPLE-ORIENTED MANAGEMENT

Małgorzata Baran,

Barbara Sypniewska

whether the superior informs employees about problems that a company or department is experiencing or not. While active participation was concerned with the statements about the possibilities of objecting to the proposed or reached decisions; expressing permission to the proposed or reached decisions; and solving problems or making decisions jointly. The statements pertaining to passive and active participation are based on the concept proposed by K. Tegtmeier (Ziemniewicz, 1991).

Statements about mentoring referred to: the supervisors' support of employee participation in mentoring programmes; the superior acting as a mentor; and workers assuming the role of the mentor for others. The questionnaire also contained questions about how often the respondents-employees turn to their superiors with personal issues and ask for help as well as the way contact is established with their superior - is it easy, hindered, or outright difficult to make.

Ultimately, the responses provided by 975 respondents out of all the people under examination - 630 women $(64.6 \%)$ and 345 men $(35.4 \%)$ - were qualified to be analysed in this paper. There were $637(65.3 \%)$ people aged between 20 and 29, 209 people $(21.4 \%)$ aged 30-39, 103 people (10.6\%) aged 40-49, and 24 people $(2.5 \%)$ aged $50-60$. Three people in the group $(0.2 \%)$ were over 60 years old. Four hundred and ninety-four people under analysis $(50.7 \%)$ had higher education and 481 people $(49,3 \%)$ had secondary education. One hundred and ninety-three people (19.8\%) held a managerial position, 297 people $(30.5 \%)$ held an expert position, 93 people $(9.5 \%)$ were blue collar workers, 278 people $(28.5 \%)$ - white collar workers, 77 people $(7.9 \%)$ were traders, and $37(3.8 \%)$ held other positions. Three hundred and ninety-one people $(40.1 \%)$ worked in service companies, 95 people $(9.7 \%)$ - in manufacturing companies, 211 people $(21.6 \%)$ - in trading companies, 164 people $(16.8 \%)$ - in mixed companies, and $114(11.7 \%)$ - in other companies. Six hundred and forty-two people $(65.8 \%)$ worked in companies with the Polish capital, 216 people $(22.2 \%)$ - in companies with the foreign capital, and 117 people (12.0\%) - in companies with mixed capital. One hundred and thirty-four respondents $(13.7 \%)$ worked in companies employing up to 9 people, 255 respondents (26.2\%) - in companies employing between 10 and 49 people, 219 respondents (22.5\%) - in companies employing between 50 and 249 people, and 367 respondents (37.6\%) - in companies employing at least 250 people.

Reliability of the measurement was measured with the use of Cronbach's alpha coefficients and it was high for people-oriented management $(\alpha=.85)$ and for non-people-oriented management $(\alpha=.82)$. The research tool was developed for the needs of the research project, part of which was presented in this article. At the design stage, the accuracy and reliability of the research tool was checked. After verifying the correctness of the tool, a proper examination was carried out. 


\section{Plan of statistical analysis}

In the first stage of the analysis, the Pearson's $r$ correlation was carried out to examine the correlations among supporting mentoring processes in a company by the superior, fulfilling the role of the mentor by the superior, and fulfilling the role of the mentor by employees.

The correlations among active and passive participation in management, people-oriented and non-people-oriented management, and relations with the superior versus supporting mentoring processes by the superior, fulfilling the role of the mentor by the superior, and fulfilling the role of the mentor by employees were also analysed with the Pearson's $r$ correlation. The relations with the superior were analysed as the possibility to turn to the superior with one's personal problems or for help and the possibility of establishing contact between employees and the superior.

In the second stage of the analysis, stepwise regression analysis was carried out. Based on the results of the regression analysis, the factors that had the greatest significance for mentoring in companies were singled out.

\section{Research results}

Pearson's $r$ correlation analysis was conducted to identify the correlations occurring for supporting mentoring processes in a company by the superior, fulfilling the role of the mentor by the superior, and fulfilling the role of the mentor by employees. Table 1 presents Pearson's $r$ correlation coefficients among the variables enumerated above; the statistically significant correlations are highlighted.

\begin{tabular}{llll}
\hline Variables & $\mathbf{1 .}$ & $\mathbf{2 .}$ & $\mathbf{3 .}$ \\
\hline $\begin{array}{l}\text { 1. Supporting the mentoring processes in a company } \\
\text { by the superior }\end{array}$ & - & & \\
\hline $\begin{array}{l}\text { 2. Fulfilling the role of the mentor by } \\
\text { the superior }\end{array}$ & $0.614^{* *}$ & - & \\
\hline $\begin{array}{l}\text { 3. Fulfilling the role of the mentor by employees } \\
\text {. }\end{array}$ & $0.401^{* *}$ & $0.381^{* *}$ & - \\
\hline
\end{tabular}

$* * p<0.01$

Statistically significant positive correlations were obtained. The strongest correlation was found between supporting mentoring processes by the superior and fulfilling the role of the mentor by the superior. This means that the superior supporting the mentoring process in a company is simultaneously the mentor, which seems logical. The weakest correlation was discovered between fulfilling the role of the mentor by the superior and fulfilling the role of the mentor by employees.
THE SIGNIFICANCE OF PEOPLE-ORIENTED MANAGEMENT

Małgorzata Baran, Barbara Sypniewska

Table 1. Pearson's $r$ correlation coefficients for supporting mentoring processes in a company by the superior, fulfilling the role of the mentor by the superior, and fulfilling the role of the mentor by employees

Source: own work based on own study 
THE SIGNIFICANCE OF PEOPLE-ORIENTED MANAGEMENT

Małgorzata Baran, Barbara Sypniewska

Table 2.

Pearson's $r$ correlation coefficients between active and passive participation in company management, people-oriented and non-people-oriented management, frequently turning to the superior with personal problems or for help, ease of contact with the superior versus supporting mentoring processes in a company by the superior, fulfilling the role of the mentor by the superior, and fulfilling the role of the mentor by employees

Source: own work based on own study
Next, the correlations among the following variables were tested: active and passive participation in company management, people-oriented and non-peopleoriented management, and relations with the superior (i.e., the possibility of frequently turning to the superior with personal problems or for help and the form of contact between the workers and the superior) and supporting mentoring processes in a company by the superior, fulfilling the role of a mentor by the superior, and fulfilling the role of a mentor by employees.

Firstly, the results were examined in terms of the possibilities that employees have in terms of turning to the superior with personal problems or for help. It turned out that over $50 \%$ of the respondents rarely turn to the superior, $30 \%$ of respondents - frequently, and only $15 \%$ - do not turn to the superior with problems or for help at all.

Subsequently, it was verified what are the possibilities of establishing contact between the workers and the superior and whether the contact is easy to establish, hindered or outright difficult. It turned out that the majority of the respondents (66.4\%) found it easy to contact the superior; $16 \%$ of the respondents assessed that more effort is needed to communicate with the superior; and $9.8 \%$ of the respondents answered that for various reasons it may be hindered. Only $7.8 \%$ of the respondents claimed that they rather do not make contact with the superior.

The next step in the course of the research process was to carry out the Pearson's r correlation analysis to examine the correlations among the following variables: active and passive participation in company management, peopleoriented and non-people-oriented management, frequently turning to the superior with personal problems or for help, ease of contact with the superior versus supporting mentoring processes in a company by the superior, fulfilling the role of the mentor by the superior, and fulfilling the role of the mentor by employees (Table 2).

\begin{tabular}{llll}
\hline Variables & $\begin{array}{l}\text { Supporting men- } \\
\text { toring }\end{array}$ & $\begin{array}{l}\text { The superior } \\
\text { as the mentor }\end{array}$ & $\begin{array}{l}\text { Employees } \\
\text { as mentors }\end{array}$ \\
\hline Passive participation & $0.386^{* *}$ & $0.389^{* *}$ & $0.263^{* *}$ \\
\hline Active participation & $0.477^{* *}$ & $0.447^{* *}$ & $0.343^{* *}$ \\
\hline People-oriented management & $0.529^{* *}$ & $0.534^{* *}$ & $0.303^{* *}$ \\
\hline Non-people-oriented management & $-0.399^{* *}$ & $-0.415^{* *}$ & $-0.129^{* *}$ \\
\hline Frequent turning to the superior & $0.281^{* *}$ & $0.334^{* *}$ & $0.216^{* *}$ \\
\hline $\begin{array}{l}\text { Ease of establishing contact with } \\
\text { the superior }\end{array}$ & $0.370^{* *}$ & $0.366^{* *}$ & $0.157^{* *}$ \\
\hline
\end{tabular}

** $p<0.01$

The analysis led to the discovery of statistically significant positive correlations among all the variables (i.e. supporting mentoring processes in a company by the 
superior; fulfilling the role of the mentor by the superior; and fulfilling the role of the mentor by employees versus passive and active participation in company management; people-oriented management; the possibility of frequently turning to the superior with personal problems or for help; and ease of contact between employees and the superior). Whereas it occurred that non-people-oriented management was negatively correlated with supporting mentoring processes in a company by the superior, fulfilling the role of the mentor by the superior, and fulfilling the role of the mentor by employees. This means that the more intense the non-people-oriented management, the less support of the superior is shown towards mentoring processes in a company, the less commonly the superior assumes the role of the mentor, and the less frequently the workers fulfil the role of the mentor.

In view of a large number of correlations obtained in the course of analysis, to sort out the conclusions, correlation analysis presented in Table 2 was supplemented with regression analysis. The three aspects of mentoring under analysis, i.e. supporting mentoring by the superior, fulfilling the role of the mentor by the superior, and fulfilling the role of the mentor by employees were one by one examined in three separate stepwise regression models.

The first model of stepwise regression analysis was the analysis in which the dependent variable was supporting mentoring in a company by the superior. The obtained results are presented in Table 3 .

The results of the analysis demonstrate the existence of statistically significant positive correlations between supporting mentoring by the superior and people-oriented management, active participation, ease of contact with the superior and frequently turning to the superior. Evidently, there is no passive participation in this model; it was rejected in the course of statistical analysis as the weakest variable. The largest percentage of variance of supporting mentoring in a company by the superior $(28.0 \%)$ was accounted for by the intensity of people-oriented management. Based on the stepwise method, active participation, ease of contact with the superior, and frequently turning to the superior were also included in the model. They accounted for 5.4\%, 1.0\%, and $0.5 \%$ of variance of supporting mentoring by the superior, respectively; therefore, the correlations with these variables were considerably weaker. This means that the key factor for the process of supporting mentoring by the superior is people-oriented management. So if people-oriented management is exercised in an organization, mentoring is usually supported by the superior. The results also demonstrate that if there is active participation in the organization, the superior will also be supporting mentoring, however, it is not as significant as people-oriented management. Similar is the case with the following variables: ease of contact with the superior and subordinates frequently turning to the superior. The significance of these variables for supporting mentoring by

THE SIGNIFICANCE OF PEOPLE-ORIENTED MANAGEMENT

Małgorzata Baran, Barbara Sypniewska 
THE SIGNIFICANCE OF PEOPLE-ORIENTED

MANAGEMENT

Małgorzata Baran,

Barbara Sypniewska

Table 3.

The results of stepwise regression analysis. The correlations between supporting mentoring in a company by the superior and company management, participation in company management, and contact with the superior

Source: own work based on own study

\begin{tabular}{|c|c|c|c|c|c|c|c|c|}
\hline Predictors & $B$ & Beta & $t$ & $p$ & $\Delta F$ & $D f$ & $p$ & $\Delta R^{2}$ \\
\hline $\begin{array}{l}\text { People-oriented } \\
\text { management }\end{array}$ & 0.08 & 0.53 & 19.43 & 0.001 & 377.46 & 1.973 & 0.001 & 0.28 \\
\hline $\begin{array}{l}\text { People-oriented } \\
\text { management }\end{array}$ & 0.06 & 0.38 & 12.43 & 0.001 & 79.33 & 1.972 & 0.001 & 0.05 \\
\hline +Active participation & 0.08 & 0.27 & 8.91 & 0.001 & & & & \\
\hline $\begin{array}{l}\text { People-oriented } \\
\text { management }\end{array}$ & 0.05 & 0.34 & 10.65 & 0.001 & 15.26 & 1.971 & 0.001 & 0.01 \\
\hline Active participation & 0.07 & 0.25 & 8.01 & 0.001 & & & & \\
\hline $\begin{array}{l}\text { +Ease of establishing } \\
\text { contact with the superior }\end{array}$ & 0.20 & 0.12 & 3.91 & 0.001 & & & & \\
\hline $\begin{array}{l}\text { People-oriented } \\
\text { management }\end{array}$ & 0.05 & 0.33 & 10.29 & 0.001 & 6.75 & 1.970 & 0.010 & 0.01 \\
\hline Active participation & 0.07 & 0.24 & 7.54 & 0.001 & & & & \\
\hline $\begin{array}{l}\text { Ease of establishing } \\
\text { contact with the superior }\end{array}$ & 0.18 & 0.10 & 3.45 & 0.001 & & & & \\
\hline $\begin{array}{l}+ \text { Frequent turning } \\
\text { to the superior }\end{array}$ & 0.13 & 0.07 & 2.60 & 0.010 & & & & \\
\hline
\end{tabular}

$B$ - non-standardized regression coefficients; Beta - standardized regression coefficients; $t$ - the value of the test for statistical significance of a predictor; $\Delta F$ - the value of the test for statistical significance of changes in model; $d f$ - the number of the degrees of freedom; $\Delta R^{2}$ - change in the variance being explained.

the superior is considerably smaller than the significance of people-oriented management.

The second model of stepwise regression analysis was the analysis in which the dependent variable was fulfilling the role of the mentor by the superior. The results are presented in Table 4.

As the results of the analysis demonstrate, statistically significant positive correlations were found between carrying out mentoring by the superior and people-oriented management, active participation, frequently turning to the superior, ease of contact with the superior, and passive participation. The largest percentage of variance of carrying out mentoring by the superior $(28.5 \%)$ was accounted for by the intensity of people-oriented management. Based on the stepwise method, active participation, frequently turning to the superior, ease of contact with the superior, and passive participation were also included in the model. They accounted for $3.8 \%, 2.1 \%, 0.6 \%$, and $0.4 \%$ of variance of fulfilling the role of the mentor by the superior, respectively; therefore, the correlations with these variables were considerably weaker. This means that the key factor for the superior fulfilling the role of the mentor is people-oriented management. So if people-oriented management is exercised in an organization, the superior 


\begin{tabular}{|c|c|c|c|c|c|c|c|c|}
\hline Predictors & $B$ & Beta & $t$ & $p$ & $\Delta F$ & $d f$ & $p$ & $\Delta R^{2}$ \\
\hline People-oriented management & 0.09 & 0.53 & 19.72 & 0.001 & 388.79 & 1.973 & 0.001 & 0.29 \\
\hline People-oriented management & 0.07 & 0.41 & 13.31 & 0.001 & 53.85 & 1.972 & 0.001 & 0.04 \\
\hline Active participation & 0.07 & 0.23 & 7.34 & 0.001 & & & & \\
\hline People-oriented management & 0.07 & 0.38 & 12.31 & 0.001 & 31.04 & 1.971 & 0.001 & 0.02 \\
\hline Active participation & 0.06 & 0.20 & 6.30 & 0.001 & & & & \\
\hline $\begin{array}{l}\text { Frequent turning } \\
\text { to the superior }\end{array}$ & 0.30 & 0.15 & 5.57 & 0.001 & & & & \\
\hline People-oriented management & 0.06 & 0.35 & 10.94 & 0.001 & 9.48 & 1.970 & 0.002 & 0.01 \\
\hline Active participation & 0.06 & 0.18 & 5.70 & 0.001 & & & & \\
\hline $\begin{array}{l}+ \text { Frequent turning } \\
\text { to the superior }\end{array}$ & 0.28 & 0.14 & 5.03 & 0.001 & & & & \\
\hline $\begin{array}{l}\text { Easy contact } \\
\text { with the superior }\end{array}$ & 0.18 & 0.09 & 3.08 & 0.002 & & & & \\
\hline People-oriented management & 0.06 & 0.34 & 10.29 & 0.001 & 5.64 & 1.969 & 0.018 & 0.01 \\
\hline Active participation & 0.05 & 0.15 & 4.24 & 0.001 & & & & \\
\hline $\begin{array}{l}\text { Frequent turning } \\
\text { to the superior }\end{array}$ & 0.28 & 0.14 & 5.01 & 0.001 & & & & \\
\hline $\begin{array}{l}\text { Easy contact } \\
\text { with the superior }\end{array}$ & 0.16 & 0.08 & 2.77 & 0.006 & & & & \\
\hline Passive participation & 0.02 & 0.08 & 2.38 & 0.018 & & & & \\
\hline
\end{tabular}

$B$ - non-standardized regression coefficients; Beta - standardized regression coefficients; $t$ - the value of the test for statistical significance of a predictor; $\Delta F$ - the value of the test for statistical significance of changes in model; $d f$ - the number of the degrees of freedom; $\Delta R^{2}$ - change in the variance being explained.

carries out mentoring. The results demonstrate as well that if there is active participation in the organization, the superior will also be carrying out mentoring processes, however, active participation is not as significant as people-oriented management. Similar is the case with the following variables: frequently turning to the superior, ease of contact with the superior, and passive participation. The significance of these variables is considerably smaller than the significance of people-oriented management for exercising mentoring by the superior. It is worth noting that passive participation appears in this model, which was rejected in the previous one. This might mean that the presence of passive participation in an organization is also conductive to fulfilling the role of the mentor by the superior.

The third model of stepwise regression analysis was the analysis in which the dependent variable was fulfilling the role of the mentor by employees. The results are presented in Table 5. 
Table 5.

The results of stepwise regression analysis. The correlations between fulfilling the role of the mentor by employees and company management, participation, and contact with the superior

Source: Own work based on own study

\begin{tabular}{|c|c|c|c|c|c|c|c|c|}
\hline Predictors & $B$ & Beta & $t$ & $p$ & $\Delta F$ & $d f$ & $p$ & $\Delta R^{2}$ \\
\hline Active participation & 0.10 & 0.34 & 11.39 & 0.001 & 129.72 & 1.973 & 0.001 & 0.12 \\
\hline Active participation & 0.07 & 0.25 & 7.24 & 0.001 & 23.08 & 1.972 & 0.001 & 0.02 \\
\hline $\begin{array}{l}\text { +People-oriented } \\
\text { management }\end{array}$ & 0.03 & 0.17 & 4.80 & 0.001 & & & & \\
\hline Active participation & 0.08 & 0.28 & 7.88 & 0.001 & 18.89 & 1.971 & 0.001 & 0.02 \\
\hline People-oriented management & 0.04 & 0.27 & 6.45 & 0.001 & & & & \\
\hline $\begin{array}{l}\text { +Non-people-oriented } \\
\text { management }\end{array}$ & 0.03 & 0.17 & 4.35 & 0.001 & & & & \\
\hline Active participation & 0.07 & 0.26 & 7.22 & 0.001 & 11.37 & 1.970 & 0.001 & 0.01 \\
\hline People-oriented management & 0.04 & 0.25 & 6.05 & 0.001 & & & & \\
\hline $\begin{array}{l}\text { Non-people-oriented manage- } \\
\text { ment }\end{array}$ & 0.03 & 0.18 & 4.57 & 0.001 & & & & \\
\hline $\begin{array}{l}+ \text { Frequent turning } \\
\text { to the superior }\end{array}$ & 0.19 & 0.11 & 3.37 & 0.001 & & & & \\
\hline
\end{tabular}

$B$ - non-standardized regression coefficients; Beta - standardized regression coefficients; $t$ - the value of the test for statistical significance of a predictor; $\Delta F$ - the value of the test for statistical significance of changes in model; $d f$ - the number of the degrees of freedom; $\Delta R^{2}-$ change in the variance being explained.

Based on the third stepwise regression analysis, statistically significant positive correlations were discovered between carrying out mentoring by employees and active participation, people-oriented management, non-people-oriented management, and frequent turning to the superior. The largest percentage of variance of fulfilling the role of the mentor by employees (11.8\%) was accounted for by the degree of active participation. Based on the stepwise method, peopleoriented management, non-people-oriented management, and frequently turning to the superior were also included in the model. They accounted for $2.0 \%, 1.6 \%$, and $1.0 \%$ of variance of supporting mentoring by employees, respectively; therefore, the correlations with these variables were considerably weaker. This means that the key factor for the process of carrying out mentoring by employees is active participation. Thus if active participation is present in an organization, employees take part in mentoring processes. The results also show that if there is peopleoriented management in an organization, non-people-oriented management, and frequently turning to the superior, employees carry out mentoring, however, these factors are not as significant as active participation. The significance of these variables is considerably smaller for carrying out mentoring by employees than active participation. It is noteworthy that passive participation appeared in this model. The in-depth statistical analysis (i.e. stepwise regression analysis) led to the rejection of ease of contact with the superior from this model, most likely 
due to the smallest and negligible significance of this predictor for carrying out mentoring by employees.

\section{Conclusion}

As demonstrated by the results of the study, the presence of people-oriented management in an organisation is the most significant factor for supporting mentoring in an organization and carrying out mentoring processes both by the superior and his or her employees. Therefore, if employees are treated in an organization as a value in itself, as partners in discussion and cooperation, they are trusted and respected, treated as creative and entrepreneurial individuals, their willingness to act is stimulated, they are offered support, and their work is appreciated, the mentoring process has a great chance of occurring and being successful.

The findings of the analysis show that the more intense the non-peopleoriented management in a company, the less support for mentoring is offered by the superior, the less intensely the superior fulfils the role of the mentor, and the less frequently employees assume the role of the mentor. It is, therefore, difficult to develop mentoring processes in an organization where employees are treated as a source of profit only and thought of as pegs in a machine, where workers are constantly kept under control, and their successes are ignored and go unnoticed. The same is the case with employees in an organization where they are divided into better and worse ones, the atmosphere of strong competition prevails, and the workers are seen as lazy and dishonest in advance. Active participation in supporting mentoring by the superior also carries significance for the mentoring processes in a company. As regression analysis demonstrates, its significance for mentoring is not as considerable as people-oriented management though. Active participation is concerned with the possibilities of objecting to the proposed or reached decisions; expressing permission to the proposed or reached decisions; solving problems or making decisions jointly and the superior is open to such participation. The superior himself or herself is key in this process as he or she gives employees such opportunities by facilitating easy contact with him or her and encouraging to make conversations and ask for help. If the superior assumes the role of the mentor, it is accompanied by: active participation, frequently turning to the superior, and passive participation. Nevertheless, these variables are not as important as the presence of people-oriented management in an organisation. As demonstrated by the research results, apart from active participation - passive participation appeared in the study as well, which pertains to employees' possibilities of making complaints; receiving advice in problematic situations; expressing their opinion about the circumstances surrounding the company and the department as well as decisions; and whether the superior informs employees about problems that a company or department is experiencing.
THE SIGNIFICANCE OF PEOPLE-ORIENTED MANAGEMENT

Małgorzata Baran, Barbara Sypniewska 
THE SIGNIFICANCE OF PEOPLE-ORIENTED MANAGEMENT

Małgorzata Baran, Barbara Sypniewska
Perhaps the presence of passive participation in an organization also encourages the superior to act as the mentor. Hence fulfilling the role of the mentor by the superior may occur concurrently with the previously mentioned manifestations of employee participation that the literature generally refers to as direct participation. As far as carrying out mentoring by employees is concerned, the key aspect in this process is active participation. Therefore, if employees are given the chance to voice their objection to the proposed or reached decisions in a company; to give their approval to the proposed or reached decisions; to resolve problems and make decisions jointly, they also fulfil the role of mentors for other employees. Contact with the superior is less significant. Perhaps such contact is not that necessary when employees themselves act as mentors for others, which seems logical. As far as the presence of employees in the role of mentors is concerned, non-peopleoriented management is of smaller significance but still recognised in the study. It might be a certain type of a motivator for employees to be the mentors in order to help others in a difficult working environment and unfavourable atmosphere.

To summarise the above findings, the significance of people-oriented management and employee participation in organizations for the proper carrying out of mentoring should certainly be stressed. Previous studies on mentoring indicate different aspects of its success, but so far the mentoring process has not been examined in terms of the impact of such variables as the ones presented in this paper and with the use of such models as the ones described here. The research has noticeable limitations. It should be emphasized that the study was an exploratory survey and the generalization of results on the entire population of companies is unauthorized, due to its unrepresentativeness. It is recommended that the size of the research sample be increased for further analyses so that it is possible to generalize the conclusions onto the total population and include other variables as well. Despite the limitations, the results suggest important practical implications and thus contribute to a better understanding of the influence of management methods on the success of mentoring and advocate reinforcement of the practices of human resources management. The authors are well aware of the fact that the paper does not exhaust the research problem and is merely a trigger for further research on mentoring processes in organisations.

\section{References}

Allen, T.D. (2007), "Mentoring Relationships From the Perspective of the Mentor", in: Ragins, B.R., Kram, K.E. (Eds.), The Handbook of Mentoring at Work: Theory, Research, and Practice, Thousand Oaks, pp. 123-147.

Baran, M. (2016a), „Profil kompetencyjny profesjonalnego mentora”, Nauki o Zarzadzaniu. Management Studies, Vol. 2 No. 27, pp. 22-32.

Baran, M. (2016b), “The Mentor's Role Within the Company”, Studia i Materiaty, Vol. 2 No. 21, pp. 132-142. 
Barney, J.B., Wright, P.M. (1998), “On becoming a strategic partner: The role of human resources in competitive advantage", Human Resource Management, Vol. 37, No. 1, pp. 31-46.

Blikle, A. (2017), Doktryna jakości. Rzecz o turkusowej samoorganizacji, Wydawnictwo Helion, Gliwice.

Butler, J.E., Ferris, G.R., Napier, N.K. (1991), Strategy and Human Resources Management, South-Western Publishing, Cincinnati.

Cascio, W.F. (1992), Managing Human Resources. Productivity, Quality of Work Life, Profis, McGraw-Hill, New York.

Chodorek, M. (2016), Uwarunkowania zarzqdzania talentami w przedsiębiorstwie w kontekście teorii pozytywnego zarządzania, Wydawnictwo Uniwersytetu Mikołaja Kopernika, Toruń.

Chyłek, M. (2011), „Współczesne zarządzanie przedsiębiorstwem a partycypacja pracownicza", Zeszyty Naukowe Uniwersytetu Przyrodniczo-Humanistycznego w Siedlcach, No. 90, pp. 181-194.

Clutterbuck, D. (2002), Każdy potrzebuje mentora. Jak kierować, Wydawnictwo PETIT, Warszawa.

Delaney, J.T., Huselid, M.A. (1996), "The impact of human resource management practices on perceptions of organizational performance", Academy of Management Journal, Vol. 39 No. 4, pp. 949-969. DOI: 10.5465/256718

Gableta, M. (2004), Człowiek i praca w zmieniającym się przedsiębiorstwie, WAE im. Oskara Langego we Wrocławiu, Wrocław.

Garvey, B., Alred, G. (2001), "Mentoring and the tolerance of complexity", Futures, Vol. 33 No. 6, pp. 519-530.

Grajewski, P. (2010), „Uwarunkowania i paradygmaty jako kategorie opisu rzeczywistości”, in: Czerska, M., Szpitter, A. (Eds.), Koncepcje zarządzania, C.H. Beck, Warszawa, pp. 115-127.

Hsu, I.C., Yeh-Yun Lin, C., Lawler, J.J., Wu, S.H. (2007), “Toward a model of organizational human capital development: Preliminary evidence from Taiwan", Asia Pacific Business Review, Vol. 13 No. 2, pp. 251-275. DOI: 10.1080/13602380701233547.

Ignyś, A. (2014), “Analiza wykorzystania bezpośredniej partycypacji pracowniczej jako formy zaangażowania pracowników w zarządzaniu współczesnymi organizacjami”, Studia Oeconomica Posnaniensia, Vol. 2 No. 10, pp. 141-157.

Ignyś, A. (2014), „Zaangażowanie pracowników w doskonalenie przedsiębiorstw - bezpośrednia partycypacja pracownicza”, Prace Naukowe Uniwersytetu Ekonomicznego we Wrocławiu, No. 357.

Karwala, S. (2009), Mentoring jako strategia wspierajaca wszechstronny rozwój osobisty, Wyższa Szkoła Biznesu-National Luis University, Nowy Sącz.

Knudsen, H. (1995), Employee Participation In Europe, SAGE Publications, LondonThousand Oaks-New Dehli.

Król, H. (2006), Transformacja pracy i funkcji personalnej, in: Król, H., Ludwiczyński, A. (Eds.), Zarządzanie zasobami ludzkimi. Tworzenie kapitału ludzkiego w organizacji, Wydawnictwo Naukowe PWN, Warszawa, pp. 17-49.

Kurnal, J. (1969), Zarys teorii organizacji i zarządzania, Polskie Wydawnictwo Ekonomiczne, Warszawa. 
THE SIGNIFICANCE OF PEOPLE-ORIENTED MANAGEMENT

Małgorzata Baran, Barbara Sypniewska
Łochnicka, D. (2013), „Zakres i efekty stosowania bezpośredniej partycypacji pracowniczej w polskich przedsiębiorstwach", Zeszyty Naukowe Wyższej Szkoły Bankowej we Wroctawiu, No. 4 (36), pp. 151-169.

Marchington, M., Kynighou, A. (2012), "The dynamics of employee involvement and participation during turbulent Times", The International Journal of Human Resource Management, Vol. 23 No. 16, pp. 3336-3354. DOI: 10.1080/09585192.2012.689161

Martyniak, Z. (2002), Historia myśli organizatorskiej. Wybitni autorzy z zakresu organizacji i zarzadzania w pierwszej połowie XX w., Akademia Ekonomiczna w Krakowie, Kraków.

Mendel, T. (2001), Partycypacja w zarzq̨dzaniu współczesnymi organizacjami, Akademia Ekonomiczna w Poznaniu, Poznań.

Mikuła, B. (2001), „Diagnozowanie stopnia partycypacji bezpośredniej pracowników”, Zeszyty Naukowe Akademii Ekonomicznej w Krakowie, No. 564, pp. 25-38

Moczulska, M. (2011), Bezpośrednia partycypacja pracowników w zarzq̨dzaniu przedsiębiorstwem. Możliwości, przesłanki, uwarunkowania, Oficyna Wydawnicza Uniwersytetu Zielonogórskiego, Zielona Góra.

Oleksyn, T. (2006), Zarządzanie kompetencjami, Oficyna Ekonomiczna, Kraków.

Parsloe, E. (2000), Coaching i mentoring, Petit, Warszawa.

Parsloe, E., Wray, M. (2002), Trener i Mentor, Oficyna Wydawnicza, Kraków.

Piotrowski, K., Świątkowski, M. (2000), Kierowanie zespołami ludzi, Bellona, Warszawa.

Pocztowski, A. (2008), Zarzadzanie zasobami ludzkimi. Strategie - procesy - metody, Polskie Wydawnictwo Ekonomiczne, Warszawa.

Robbins, S.P., DeCenzo, D.A. (2002), Podstawy zarzadzania, Polskie Wydawnictwo Ekonomiczne, Warszawa.

Rybak, M. (2004), Etyka menedżera - społeczna odpowiedzialność przedsiębiorstwa, Wydawnictwo Naukowe PWN, Warszawa.

Sandberg, J. (2000), "Understanding human competence at work: An interpretive approach", Academy of Management Journal, Vol. 43 No. 1, pp. 9-25. DOI: $10.2307 / 1556383$

Sekuła, Z. (2015), „Partycypacja pracowników w zarządzaniu a dialog społeczny na poziomie zakładu pracy", Gospodarka Rynek Edukacja, Vol. 16 No. 3, pp. 5-11.

Shea, G. (1992), Mentoring: A Guide to the Basics, Kogan Page, London.

Suchar, M. (2003), Kariera i rozwój zawodowy, Ośrodek Doradztwa i Doskonalenia Kadr Sp. z o.o., Gdańsk.

Sypniewska, B.A. (2016), Godnościowa satysfakcja pracownicza, in: Oleksyn, T., Sypniewska, B.A. (Eds.), Zarządzanie zasobami ludzkimi. Refleksje teoretyczne, kwestie praktyczne, WSFiZ, Warszawa, pp. 359-374.

Wang, D., Chen, S. (2013), "Does Intellectual Capital Matter? High-Performance Work Systems and Bilateral Innovative Capabilities", International Journal of Manpower, Vol. 34 No. 8, pp. 861-879. DOI: 10.1108/IJM-07-2013-0167.

Zając, Cz. (2014), „Skuteczne zarządzanie kapitałem ludzkim jako czynnik sukcesu przedsiębiorstwa", Zarządzanie i Finanse, Vol. 12 No. 1, pp. 195-207.

Ziemniewicz K. (1991), Techniki zarządzania, Polskie Wydawnictwo Ekonomiczne, Warszawa. 